\title{
MS/MS of Protonated Polyproline Peptides: \\ The Influence of N-terminal Protonation \\ on Dissociation
}

\author{
Anita G. Unnithan, Matthew J. Myer, Christopher J. Veale, \\ and Allison S. Danell \\ Department of Chemistry, East Carolina University, Greenville, North Carolina, USA
}

A unique collision-induced dissociation pattern was observed for protonated polyproline peptides of length $n$ in which $\mathrm{y}_{n-2}$ and/or $\mathrm{y}_{n-4}$ ions were formed in much higher abundance than any other product ions. Cleavage occurs only at every other amide bond, such that product ions are formed only from the losses of even numbers of proline residues. Exclusive losses of even numbers of proline residues were not observed from sodiated peptides. Further study of the tandem mass spectrometry (MS/MS) patterns of protonated proline-rich peptides showed that the substitution of alanine in the second position of polyproline peptides did not prevent the dominant formation of $\mathrm{y}_{n-2}$ and $\mathrm{y}_{n-4}$ ions. The loss of ProAla to form the $\mathrm{y}_{8}$ ion from (ProAlaPro $\left.{ }_{8} \mathrm{NH}_{2}+\mathrm{H}\right)^{+}$was as abundant as the loss of ProPro from $\left(\mathrm{Pro}_{10} \mathrm{NH}_{2}+\mathrm{H}\right)^{+}$. However, modification of the peptides that presumably affected the location of the proton on the peptide did alter the MS/MS spectra. $\mathrm{Pro}_{10}$ and $\mathrm{Pro}_{5}$ with blocked N-termini or with arginine substituted for the first proline residue did not form abundant $\mathrm{y}_{n-2}$ or $\mathrm{y}_{n-4}$ ions. MS ${ }^{3}$ and double resonance experiments showed that dissociation of intermediate $\mathrm{y}_{n}$ product ions can produce $\mathrm{y}_{n-2}$ ions, but are not necessary dissociation pathway intermediates. This analysis suggests that the ionizing proton must be located at the N-terminus for the peptide ion to dissociate in this manner. (J Am Soc Mass Spectrom 2007, 18, 2198-2203) (C) 2007 American Society for Mass Spectrometry

$\mathrm{P}$ oline (Pro) is the only naturally occurring amino acid that is bonded to the nitrogen atom of the peptide backbone. The absence of the amide hydrogen prevents polyproline peptides from forming alpha helices. Instead, two possible helical structures of polyproline can be found in solution, named ProI and ProII. ProI exists in solution as a right-handed helix with 3.3 residues per turn, and all peptide bonds are cis bonds. ProII is a left-handed helix with 3.0 residues per turn, and all peptide bonds are trans bonds. The type of helix formed varies with the type of solvent in which the polyproline is dissolved. ProI is found in less protic solvents such as butanol or propanol, whereas ProII exists in more protic solvents such as water. Counterman and Clemmer [1] have shown with ion mobility spectrometry and supporting computational studies that when polyproline peptides are introduced into the gas phase from propanol solutions, features of the ProI helix persist in the gas phase. This was observed for many different lengths of polyproline chains. However, electrospray ionization (ESI) of aqueous solutions did not produce ion mobility data consistent with ProII helices. It was reasoned that the elongated structure of

Address reprint requests to Prof. Allison Stokes Danell, East Carolina University, Department of Chemistry, 300 Science and Technology Building, Greenville, NC 27858, USA. E-mail: danella@ecu.edu the ProII helix could not be stabilized in the absence of solvent $[1,2]$. It already has been established that the solvent choice has no effect on the dissociation energetics of polyproline peptides [3]. Interestingly, a unifying feature was established for all polyproline peptides examined, regardless of the original solvent. The lowest energy conformers showed hydrogen bonding between the protonated $\mathrm{N}$-terminus and the second proline [1]. Hydrogen bonding of this sort is not possible for internal Pro residues because of the absence of hydrogens on the amide nitrogens.

The proton must be located at the $\mathrm{N}$-terminus for this hydrogen bonding to occur. This is the most basic site on a polyproline peptide, and the ProI helix is stabilized with the positive charge located at the N-terminus (unlike alpha helices that are stabilized with the charge located at the C-terminus). Earlier molecular modeling studies of $\left(\mathrm{PrO}_{2}+\mathrm{H}\right)^{+}$conducted by Ewing et al. [4] also yielded a lowest-energy structure that had both hydrogens on the N-terminal nitrogen involved in hydrogen bonds with the first and second carbonyl oxygens. This consistent pattern of $\mathrm{N}$-terminal charge location over a large range of sizes of polyproline peptides provides an interesting case for studying how the identity and location of the ionizing species affect tandem mass spectrometry (MS/MS) patterns. The tandem mass spectra of protonated proline-containing peptides have 
been studied extensively because of the influence the proline residue has on the peptide dissociation pattern. The formation of $y$-ions from backbone cleavage at the N-terminal side of proline is often the most dominant fragmentation pathway $[5,6]$. The proton affinity of proline [4] and the strained structure of the complementary b-ion [5] have been proposed as reasons for the selective formation of $y$-ions. The position of the proline in tri-peptides has been shown to influence the dominance of the so-called proline effect [7-9]. The investigation into the proline effect continues, with recent experimental and computational data being generated for $\mathrm{N}$-acetyl O-methoxy proline [10] and for pentapeptides with proline and aspartic acid residues in the second and third positions [11].

In the current work, a systematic study of the MS/MS patterns of polyproline or proline-rich peptides was carried out with low-energy collision-induced dissociation (CID), protonated and sodiated, with and without modified termini, and with and without a basic residue present. A unique dissociation pattern was observed for protonated peptides in which product ions corresponding to the loss of only even numbers of N-terminal proline residues were formed. MS/MS data were collected for several model peptides, and the presence of multiple dissociation pathways was examined using $\mathrm{MS}^{3}$. Double resonance experiments also were performed to investigate the possibility that some product ions were formed sequentially through an intermediate product ion [12-14]. The relationship of the unique dissociation pattern to the potential helixinducing ionic hydrogen bond at the protonated Nterminus of polyprolines and to the sequencing of proline-rich peptides will be discussed.

\section{Experimental}

MS/MS experiments were performed on a Bruker Esquire 3000plus Quadrupole Ion Trap Mass Spectrometer (Billerica, MA, USA) using positive-mode ESI. The sample was delivered to the ESI source with a KD Scientific (Holliston, MA, USA) syringe pump at 250 $\mu \mathrm{L} / \mathrm{h}$, and the electric potential used to initiate ESI was $4000 \mathrm{~V}$. Helium was introduced at an added pressure of $3 \times 10^{-5}$ Torr. $\mathrm{MS}^{n}$ was achieved using CID, with the isolation window for the parent ion at $2.0 \mathrm{Da}$ and the $\mathrm{q}_{\mathrm{z}}$ $\approx 0.25$ for the parent ion [controlled by the low-mass cutoff setting in the Esquire software (Esquire Software Solutions, Ajman, United Arab Emirates)]. The activation time to effect CID was $40 \mathrm{~ms}$. Amplitude of the fragmentation energy was optimized to minimize parent ion intensity, maximize product ion intensity, and minimize ion ejection. Typically, a value of $0.50 \mathrm{~V}$ was the optimized fragmentation amplitude in the Esquire software.

Double resonance experiments were performed on a modified Bruker Esquire LC Quadrupole Ion Trap Mass Spectrometer, equipped with a custom nanoESI source. Isolation and fragmentation were effected with the
Esquire control software. Stored Waveform Inverse Fourier Transform (SWIFT) was used to eject product ions suspected of being reaction intermediates during CID. Waveforms were configured and built with custom LabVIEW software (National Instruments, Austin, TX, USA). Then, waveforms were loaded onto the NI PCI-5411 arbitrary waveform generator, triggered at the start of the instrument scan function. The output was applied directly to the entrance endcap (which is normally grounded). The activation time was increased from 40 to $132 \mathrm{~ms}$ so that four SWIFT pulses could be applied during CID to efficiently eject the selected product ion. Other parameters were set the same as those used on the 3000plus instrument. The scan delay feature in the Esquire software was used to postpone the mass scan until after the SWIFT and CID functions were completed.

The peptides $\mathrm{Pro}_{n}-\mathrm{NH}_{2}(n=4-10)$ and $\mathrm{ProAlaPro}_{8}-$ $\mathrm{NH}_{2}$ were synthesized in house using standard FMOC solid-phase peptide synthesis on Rink amide MBHA resin. This resin choice helped increase our success rate of coupling the first (C-terminal) proline to the resin. The peptides $\mathrm{Ac}-\mathrm{Pro}_{n}, \mathrm{ArgPro}_{n-1}-\mathrm{NH}_{2}$, and Ac-Arg$\mathrm{Pro}_{n-1}-\mathrm{NH}_{2}(n=5$ or 10$)$ were obtained from AnaSpec (San Jose, CA). All peptides were purified by reversedphase HPLC before use. Solutions were prepared in $50 / 50$ (vol/vol) $\mathrm{ACN} / \mathrm{H}_{2} \mathrm{O}$ with approximately $1 \%$ acetic acid added if desired.

\section{Results and Discussion}

CID of a protonated octamer $\left(\mathrm{Pro}_{8} \mathrm{NH}_{2}+\mathrm{H}\right)^{+}$produced an MS/MS spectrum showing exclusive y-ion formation, as shown in Figure 1a. Cleavage N-terminal to proline is expected. However, only specific $y$-ion peaks are abundant in Figure 1a; the major y-ions, $\mathrm{y}_{6}$ and $\mathrm{y}_{4}$ are formed by the loss of even numbers of proline residues from the parent ion. Figure $1 \mathrm{~b}$ shows the MS/MS spectrum of $\left(\mathrm{Pro}_{8} \mathrm{NH}_{2}+\mathrm{Na}\right)^{+}$, in which a series of y-type product ions are observed from $\left(\mathrm{y}_{3}-\mathrm{H}+\mathrm{Na}\right)^{+}$ to $\left(\mathrm{y}_{7}-\mathrm{H}+\mathrm{Na}\right)^{+}$. The losses of even numbers of proline residues from the sodiated parent ion are less pronounced than those from the protonated parent. Figure $1 \mathrm{~b}$ does not show an intense sodiated $\mathrm{y}_{4}$ ion, unlike in Figure 1a where the protonated $\mathrm{y}_{4}$ ion is the most intense ion. Additionally, cleavage between the first and second proline residues to form the $\mathrm{y}_{7}$ ion occurs in the sodiated peptide, but not the protonated peptide. Note that in Figure 1b, we do not see the typical sequential loss of C-terminal residues from these sodiated peptide ions because this peptide has a blocked C-terminus $[15,16]$. When unmodified polyproline peptides cationized with sodium were dissociated, they underwent a rearrangement to produce a peptide one residue shorter than the parent (data not shown) [15, 17-20].

Intense peaks correlating to product ions resulting from even losses of Pro residues from parent ions were observed for various lengths of polyproline peptides. 

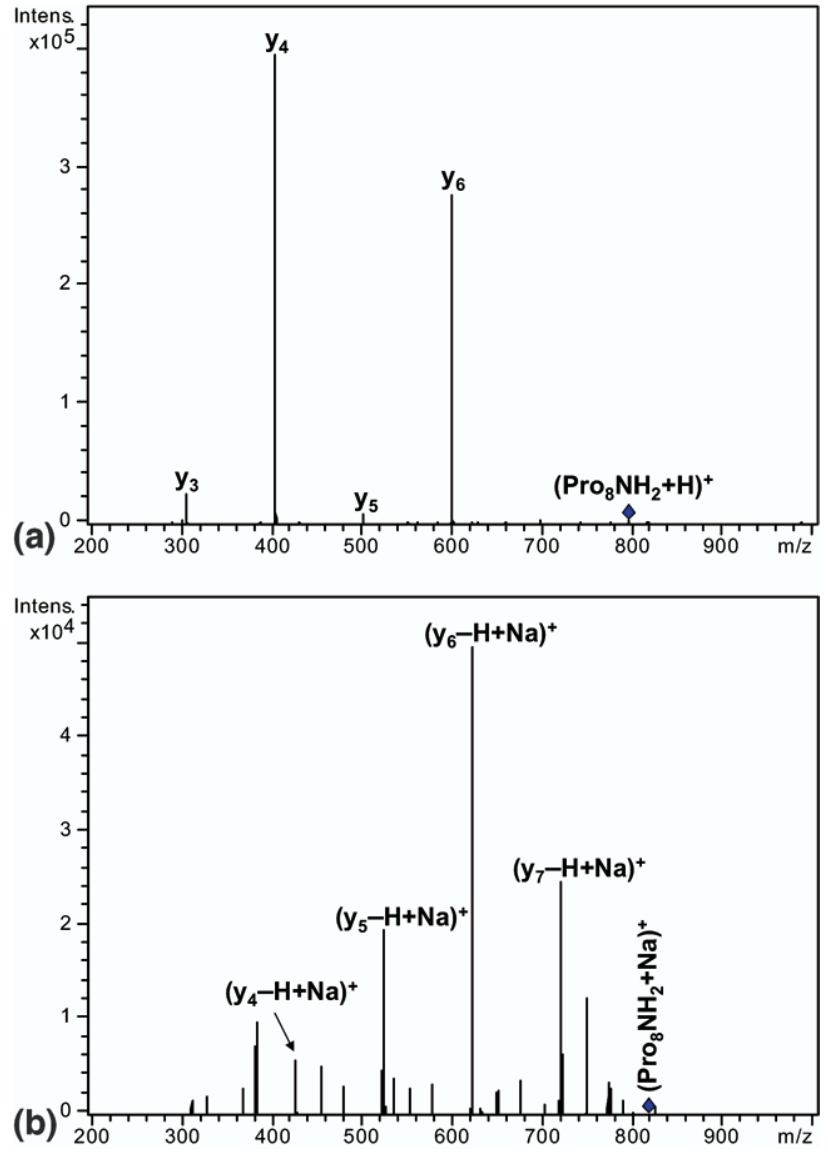

Figure 1. MS/MS spectrum of (a) $\left(\mathrm{Pro}_{8} \mathrm{NH}_{2}+\mathrm{H}\right)^{+}$and (b) $\left(\mathrm{PrO}_{8} \mathrm{NH}_{2}+\mathrm{Na}\right)^{+}$. Parent ions marked with $\bullet$.

Figure 2 is a summary of the product ion intensities for CID of $\left(\mathrm{Pro}_{n} \mathrm{NH}_{2}+\mathrm{H}\right)^{+}$, where $n=4-10$. The base peak in the spectra for $n=4-7$ is the $\mathrm{y}_{n-2}$ ion, and when $n$ is 8,9 , or 10 , the base peak is the $\mathrm{y}_{n-4}$ ion. The relative intensities of the $\mathrm{y}_{n-1}$ and $\mathrm{y}_{n-3}$ ions increase as $n$ decreases, although they never reach intensities as high as the $\mathrm{y}_{n-2}$ and $\mathrm{y}_{n-4}$ ions. CID of $\left(\mathrm{PrO}_{n} \mathrm{NH}_{2}+\mathrm{Na}\right)^{+}$ produced results similar to Figure $1 \mathrm{~b}$ (data not shown),

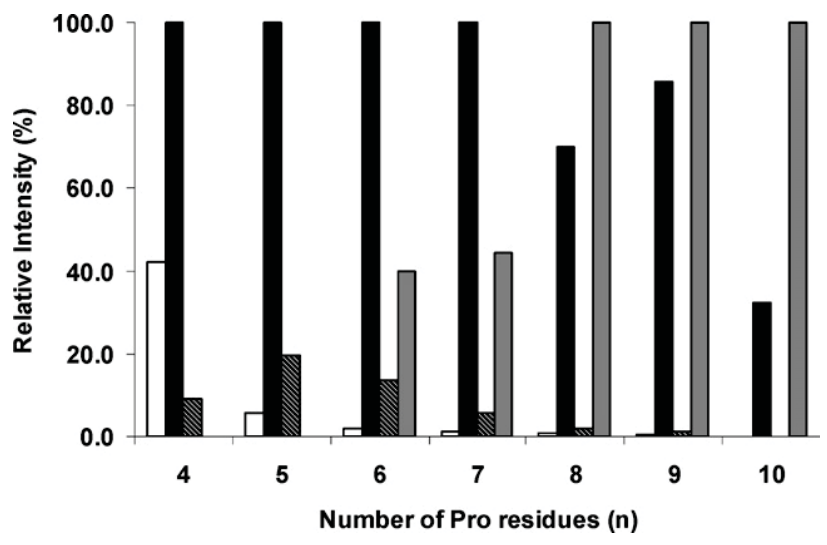

Figure 2. Relative intensities of $\mathrm{y}_{n-1}$ (white bars), $\mathrm{y}_{n-2}$ (black bars), $\mathrm{y}_{n-3}$ (striped bars), and $\mathrm{y}_{n-4}$ (grey bars) ions formed from CID of $\left(\mathrm{Pro}_{n} \mathrm{NH}_{2}+\mathrm{H}\right)^{+}$for $n=4$ to 10 .

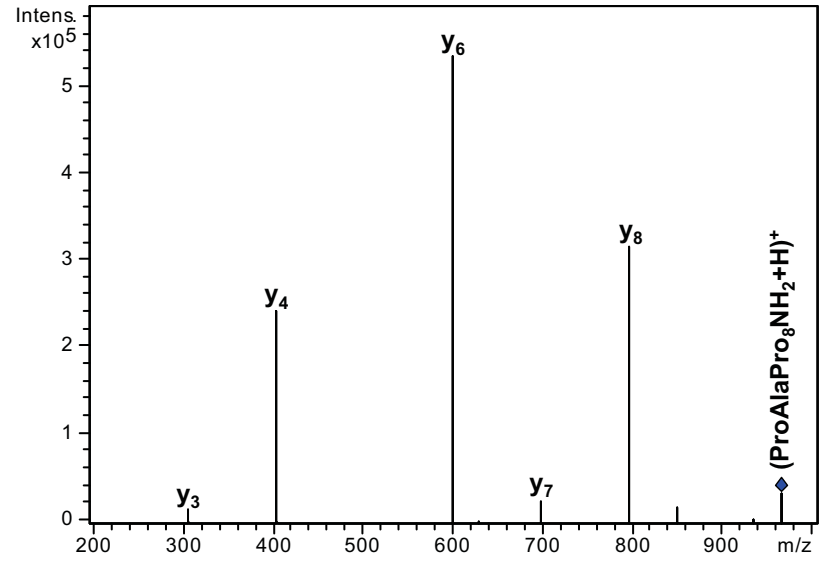

Figure 3. MS/MS spectrum of $\left(\mathrm{ProAlaPro}_{8} \mathrm{NH}_{2}+\mathrm{H}\right)^{+}$.

where sodiated $\mathrm{y}_{n-1}$ to $\mathrm{y}_{n-5}$ ions were formed, and the product ion intensities fit approximately a Gaussian shape centered about the sodiated $\mathrm{y}_{n-2}$ or $\mathrm{y}_{n-3}$ ion.

For the polyproline peptides, even numbers of Pro residues were lost from the $\mathrm{N}$-terminal end of the peptide. To determine whether the second residue in a pair must be a Pro, the repeating Pro sequence was interrupted by substituting the second amino acid in the $\operatorname{Pro}_{10} \mathrm{NH}_{2}$ peptide with Alanine (Ala). The peptide was subjected to CID, and the MS/MS spectrum for protonated ProAlaPro ${ }_{8} \mathrm{NH}_{2}$ is shown in Figure 3. The most intense product ions are the $\mathrm{y}_{8}, \mathrm{y}_{6}$, and $\mathrm{y}_{4}$ ions. Low-intensity peaks also appear for the $y_{3}, y_{7}$, and $b_{9}$ ions. Preferential formation of the $\mathrm{y}_{8}$ ion could be attributed simply to the proline effect. However, the presence of high-intensity $\mathrm{y}_{8}, \mathrm{y}_{6}$, and ${ }_{\mathrm{y} 4}$ ions collectively point to a unique dissociation pathway. For a peptide $n$ residues long, Figure 3 indicates that $\mathrm{y}_{n-2}$ formation is likely even when the cleavage is occurring between Xxx-Pro, not just Pro-Pro. Additionally, formation of $\mathrm{y}_{n-4}$ and $\mathrm{y}_{n-6}$ ions occurs regardless of the identity of the second residue in the parent ion.

Because $\mathrm{y}_{n-2}$ and $\mathrm{y}_{n-4}$ product ions are dominant in CID spectra of protonated peptides but not sodiated peptides, it appears the proton plays an important role in this dissociation behavior. To elucidate the effects of sequestering the ionizing proton on the observed MS/MS pattern, an arginine residue was introduced into the proline-repeating 10-mer peptide. The MS/MS spectrum of ArgPro $_{9} \mathrm{NH}_{2}$ is shown in Figure 4. The most intense product ion is the uninformative water loss product. As seen with CID of the other peptides performed thus far, y-type product ions are abundant. However, the most abundant product ion is the $\mathrm{y}_{5}$ ion, which corresponds to a loss of an odd number of proline residues from the parent ion. The intensities of the $\mathrm{y}_{8}, \mathrm{y}_{6}$, and $\mathrm{y}_{4}$ ions are no more significant than the intensities of the $y_{7}, y_{5}$, and $y_{3}$ ions. Similarly, CID of ArgPro $\mathrm{NH}_{2}$ resulted in the formation of $\mathrm{y}_{4}, \mathrm{y}_{3}$, and $\mathrm{y}_{2}$ ions of approximately equal intensity, with the $\left(\mathrm{M}+\mathrm{H}-\mathrm{H}_{2} \mathrm{O}\right)^{+}$ion being the base peak (data not 


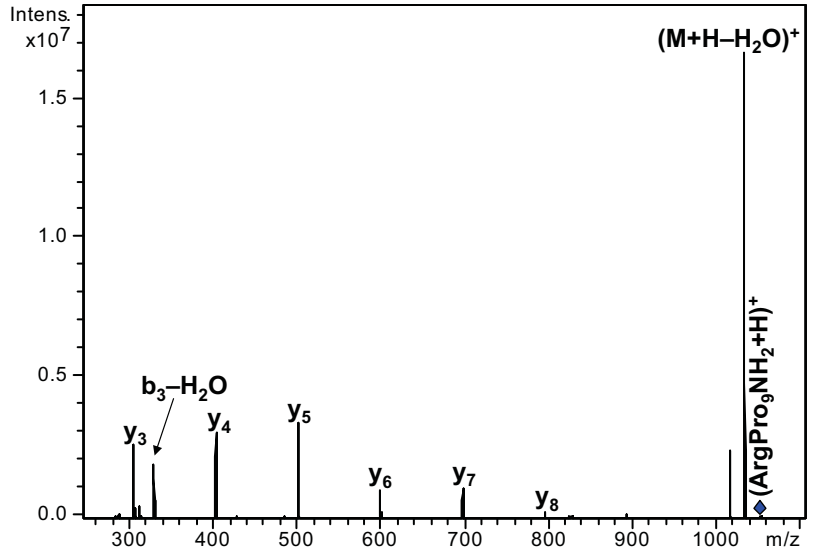

Figure 4. MS/MS spectrum of $\left(\mathrm{ArgPro}_{9} \mathrm{NH}_{2}+\mathrm{H}\right)^{+}$.

shown). We can conclude that the proton cannot be sequestered by a basic residue for the formation of $\mathrm{y}_{n-2}$ and $\mathrm{y}_{n-4}$ ions to be the major fragmentation pathway.

In the absence of a strongly basic residue in a protonated peptide, the location of the proton cannot necessarily be pinpointed [21]. The most basic site on such a peptide would be the N-terminus, provided it was unmodified. As mentioned previously, lowestenergy structures of various lengths of protonated polyproline peptides have the proton residing at the N-terminus. This allows both hydrogens on the $\mathrm{N}$ terminal nitrogen to hydrogen bond to the first and second carbonyl oxygens. When peptide ions become activated, however, the proton can be intramolecularly transferred to cleavage sites along the peptide backbone, as described by the mobile proton model [22-24]. In the production of $b$ - and y-type ions, charge-directed fragmentation of the amide bond is caused by proton migration to the amide nitrogen.

To determine whether the MS/MS pattern of even losses of proline residues is dependent on the proton being located on the N-terminus or mobilized during activation, another polyproline peptide was synthesized, this time with a blocked N-terminus. The Nterminally modified peptide, $\mathrm{AcPro}_{10}$, cannot be protonated at the N-terminus. The CID spectrum of AcPro $_{10}$ is shown in Figure 5a. Above the low- $m / z$ cutoff of $278 \mathrm{Da}$, the entire $y$-ion series is observed in Figure $5 a$. However, the most abundant ions are the $\mathrm{y}_{9}, \mathrm{y}_{7}$, and $\mathrm{y}_{5}$. Unlike in Figure 4, there is not a symmetric distribution of intensities of the y-type ions centered about the most intense y-type ion in Figure 5a. Instead, the relative intensities of the $\mathrm{y}_{9}$ down to the $\mathrm{y}_{4}$ ions alternate between high and low, making the high-intensity $\mathrm{y}_{7}$ and $\mathrm{y}_{5}$ peaks particularly noticeable. $\mathrm{MS}^{3}$ of the $\mathrm{y}_{9}$ ion is shown in Figure $5 \mathrm{~b}$. Here we can see the familiar losses of even numbers of proline residues, showing that a specific pathway for the formation of the $y_{7}$ and $\mathrm{y}_{5}$ ions exists through the $\mathrm{y}_{9}$ intermediate. The primary structure of the $\mathrm{y}_{9}$ ion from this parent ion is analogous to the $\left(\mathrm{Pro}_{9} \mathrm{NH}_{2}+\mathrm{H}\right)^{+}$ion examined earlier, except for the difference in C-termini. In comparing the $\mathrm{MS}^{3}$ spectrum of $\left(\mathrm{AcPrO}_{10}+\mathrm{H}\right)^{+} \rightarrow \mathrm{y}_{9} \rightarrow$ products (Figure $5 \mathrm{~b})$ to the MS/MS spectrum of $\left(\mathrm{Pro}_{9} \mathrm{NH}_{2}+\mathrm{H}\right)^{+}$(data Figure 2), the identities of the product ions are the same. However, the relative intensities of the $\mathrm{y}_{7} / \mathrm{y}_{5}\left(\mathrm{y}_{n-2} /\right.$ $\left.\mathrm{y}_{n-4}\right)$ ions do differ, with the $\mathrm{y}_{7}$ ion being the base peak in the $\mathrm{MS}^{3}$ spectrum but the $\mathrm{y}_{5}$ ion being the base peak in the MS/MS spectrum. Perhaps the fragmentation energies used to obtain the two spectra were optimized slightly differently such that less of the $\mathrm{y}_{5}$ ion was produced in the $\mathrm{MS}^{3}$ spectra. Regardless of the relative intensity difference, the key observation is that very intense $\mathrm{y}_{n-2}$ and $\mathrm{y}_{n-4}$ ions are produced from protonated polyproline peptides with unmodified N-termini, even if the dissociating ion is an intermediate formed from a parent ion with a blocked N-terminus.

$\mathrm{Up}$ to this point, we have seen that both $\mathrm{y}_{n-2}$ and $\mathrm{y}_{n-4}$ ions are produced from peptides with more than six Pro residues in the sequence. To establish whether the $\mathrm{y}_{n-4}$ ions are formed sequentially from $\mathrm{y}_{n-2}$ ions, a double resonance experiment was carried out. Figure 6 illustrates the differences in MS/MS spectra of $\left(\mathrm{Pro}_{7} \mathrm{NH}_{2}+\mathrm{H}\right)^{+}$when double resonance is performed. Figure 6a shows a conventional MS/MS spectrum, where the $\mathrm{y}_{5}$ and $\mathrm{y}_{3}$ ions appear as products from the 7 -mer parent ion. Figure $6 \mathrm{~b}$ was generated with an
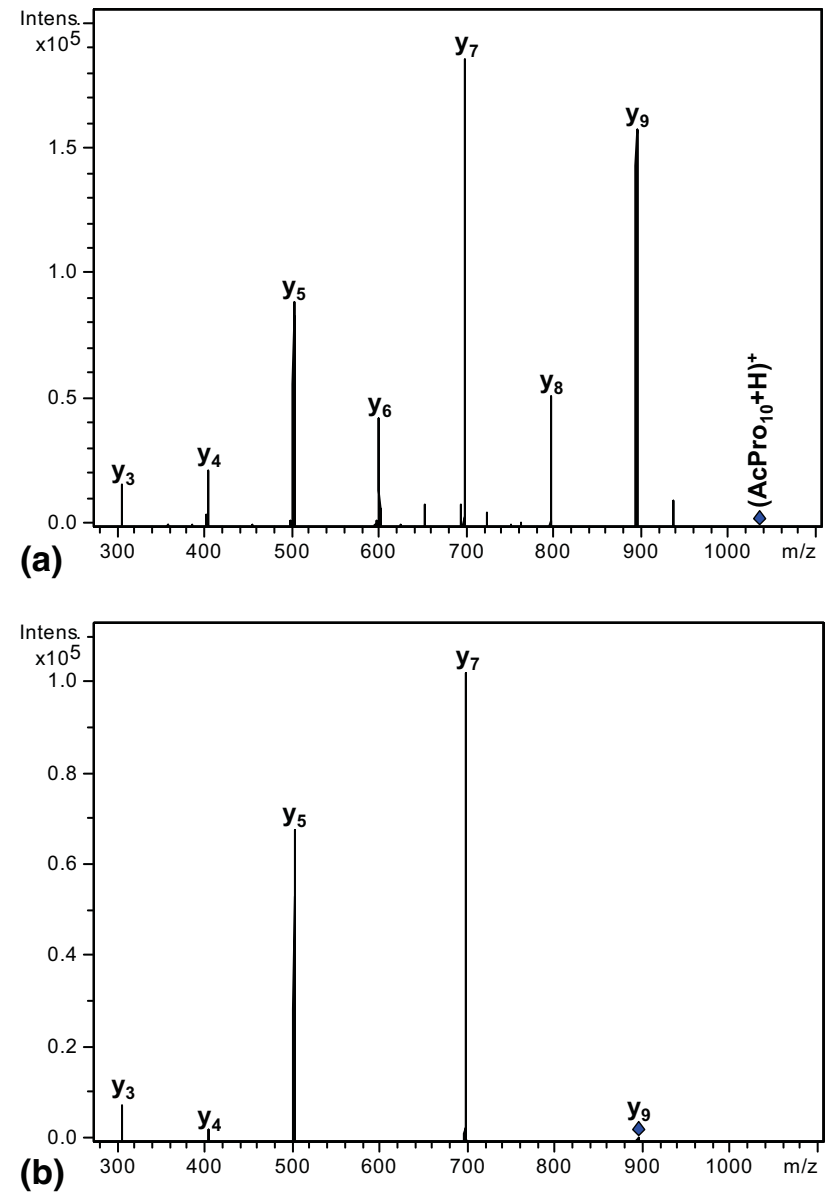

Figure 5. (a) $\mathrm{MS} / \mathrm{MS}$ spectrum $\left(\mathrm{AcPro}_{10}+\mathrm{H}\right)^{+}$and (b) $\mathrm{MS}^{3}$ spectrum of $\left(\mathrm{AcPro}_{10}+\mathrm{H}\right)^{+} \rightarrow \mathrm{y}_{9} \rightarrow$ products. 

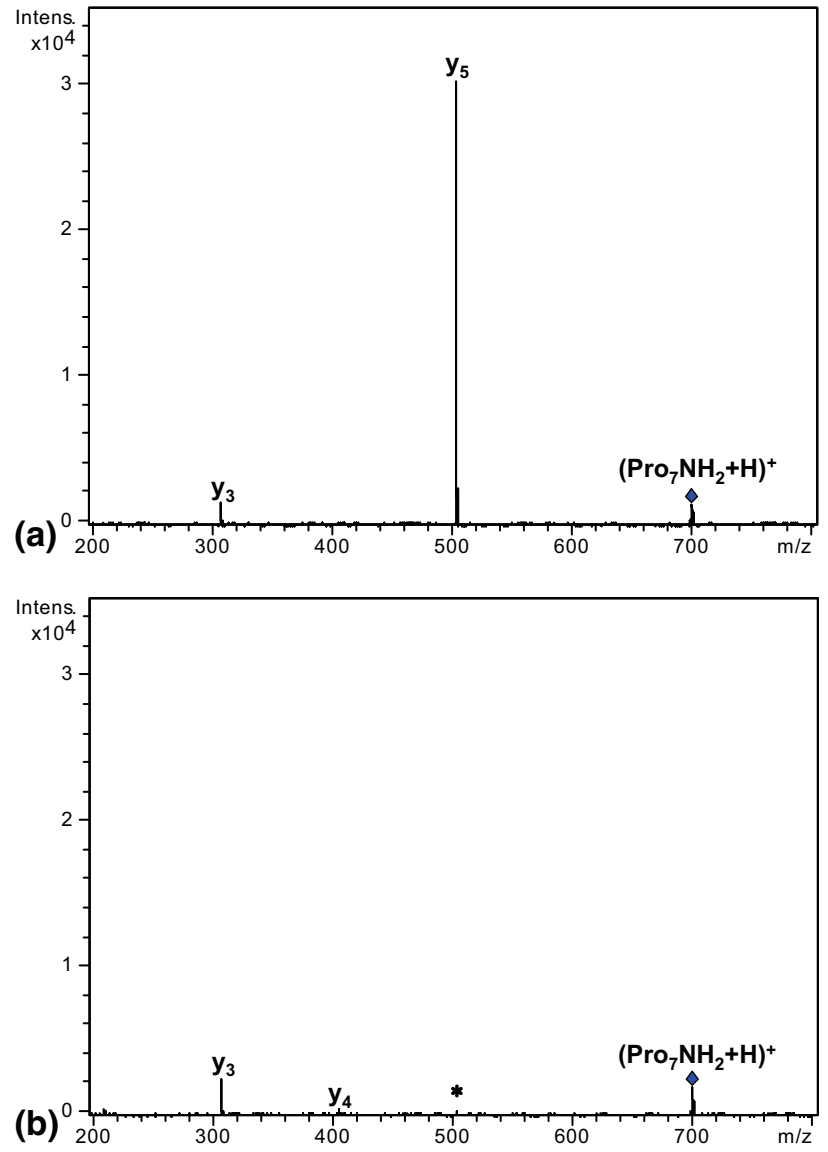

Figure 6. MS/MS spectra of $\left(\mathrm{Pro}_{7} \mathrm{NH}_{2}+\mathrm{H}\right)^{+}$(a) without double resonance and $(\mathbf{b})$ with double resonance to eject $\mathrm{y}_{5}$ ion during its production. The asterisk $\left({ }^{*}\right)$ is positioned at the $\mathrm{m} / \mathrm{z}$ value of the ejected $\mathrm{y}_{5}$ ion.

additional SWIFT waveform designed to eject the $y_{5}$ ion as it was being produced during MS/MS. The $\mathrm{y}_{5}$ ion is eliminated from the spectrum in Figure 6b. However, the $\mathrm{y}_{3}$ ion is not eliminated, indicating that the $\mathrm{y}_{3}$ ion is not a second-generation product ion formed through a $\mathrm{y}_{5}$ intermediate. The $\mathrm{y}_{n-2}$ and $\mathrm{y}_{n-4}$ ions are not produced by two-at-a-time losses of Pro residues; rather, they are produced when even numbers of Pro residues are lost from the parent ion.

The dissociating structure of protonated proline-rich peptides may have features in common with the structures generated with ion mobility spectrometry and molecular modeling data. These lowest-energy conformers show the ionized hydrogen bond at the Nterminus, and the charge at the N-terminal end acts to stabilize the ProI helix dipole. It is unlikely that the proton stays sequestered at this site because it is a relatively low-energy process to move the proton away from the $\mathrm{N}$-terminus to promote charge-directed fragmentation. However, when the proton was forced to be mobile (blocked N-terminus), the exclusive even loss fragmentation pattern was not observed. If the peptide sequences studied herein were a special case where the energy required to mobilize the proton is greater than that required to initiate fragmentation nearby (two residues away from the protonated N-terminus), then the product ion formation would likely have to be sequential in nature. That is, the proton would be transferred to a "new" N-terminus to initiate the next fragmentation step. The double resonance experiments contradict that, because the $\mathrm{y}_{n-4}$ ion appeared even when the $\mathrm{y}_{n-2}$ ion was ejected. Without simple proton mobilization or proton sequestering required, it should be considered that the proton location induces a conformational change that makes the losses of even numbers of proline favorable. Computational experiments are under way to determine how protonation at the N-terminus, in line with the Pro helix dipole, may affect the bond strength of alternating amide nitrogens or the stability of neutrals formed by even numbers of residues lost from the parent.

\section{Conclusions}

Several synthetic polyproline peptides were subjected to CID and, in certain cases, the protonated parent ion dissociated almost exclusively to $\mathrm{y}_{n-2}$ and $\mathrm{y}_{n-4}$ product ions. To observe this pattern, the N-terminus must be available for protonation, and highly basic residues must not sequester the proton elsewhere. Even with a blocked N-terminus, the subsequent formation of $y$ type ions without a "new" modified N-terminus will still dissociate further to lose an even number of residues. Study of this dissociation pattern highlights the role the ionizing proton plays in MS/MS of peptide ions without strongly basic residues, and how conformation of these species may affect dissociation. Because the second residue of the pair of residues lost does not have to be a proline, the identity of $\mathrm{Xxx}$ can be determined when the loss of ProXxx dominates in the MS/MS spectrum of a $\left(\mathrm{ProXxxPro}_{n}+\mathrm{H}\right)^{+}$peptide. This notable pattern may be useful to look for when working with proline-rich peptides and proteins. The repeating proline motif commonly appears in biologically relevant proteins, such as actin-binding proteins. The ability to detect collagens, which also have proline-rich segments, could prove important in preventing the entry of contaminated animal feed into the food chain $[25,26]$.

\section{Acknowledgments}

This work was supported by generous startup funds from East Carolina University. The authors thank Prof. Toby Allen at East Carolina University for help with peptide synthesis and Dr. Ryan Danell for LabVIEW programming.

\section{References}

1. Counterman, A. E.; Clemmer, D. E. Anhydrous Polyproline Helices and Globules. J. Phys. Chem. B 2004, 108, 4885-4898.

2. Zhong, H.; Carlson, H. A. Conformational Studies of Polyprolines. J. Chem. Theory Comput. 2006, 2, 342-353.

3. Danell, A. S.; Glish, G. L. Structural Effects on Dissociation: Polyproline. In: Proceedings of the 49th ASMS Conference on Mass Spectrometry and Allied Topics; Chicago, IL, May, 2001. 
4. Ewing, N. P.; Zhang, X.; Cassady, C. J. Determination of the Gas-Phase Basicities of Proline and Its Di- and Tripeptides with Glycine: The Enhanced Basicity of Prolylproline. J. Mass Spectrom. 1996, 31, 13451350 .

5. Vaisar, T.; Urban, J. Probing the Proline Effects in CID of Protonated Peptides. J. Mass Spectrom. 1996, 31, 1185-1187.

6. Schwartz, B. L.; Bursey, M. M. Some Proline Substituent Effects in the Tandem Mass Spectrum of Protonated Pentaalanine. Biol. Mass Spectrom. 1992, 21, 92-96.

7. Grewal, R. N. El Aribi, H. Harrison, A. G. Siu, K. W. M. Hopkinson, A. C. Fragmentation of Protonated Tripeptides: The Proline Effect Revisited. J. Phys. Chem. B 2004, 108, 4899-4908.

8. Paizs, B.; Suhai, S. Fragmentation Pathways of Protonated Peptides. Mass Spectrom. Rev. 2005, 24, 508-548.

9. Paizs, B.; Schnolzer, M.; Warnken, U.; Suhai, S.; Harrison, A. G. Cleavage of the Amide Bond of Protonated Dipeptides. Phys. Chem. Chem. Phys. 2004, 10, 2691-2699.

10. Komaromi, I.; Somogyi, A.; Wysocki, V. H. Proton Migration and Its Effect on the MS Fragmentation of N-Acetyl OMe Proline: MS/MS Experiments and $\mathrm{Ab}$ Initio and Density Functional Calculations. Int. J. Mass Spectrom. 2005, 241, 315-323.

11. Smith, L. L.; Herrmann, K. A.; Wysocki, V. H. Investigation of Gas Phase Ion Structure for Proline-Containing $b_{2}$ Ion. I. Am. Soc. Mass Spectrom. 2006, 17, 20-28.

12. Colorado, A.; Shen, J. X.; Brodbelt, J. Use of Infrared Multiphoton Photodissociation with SWIFT for Electrospray Ionization and Laser Desorption Applications in a Quadrupole Ion Trap Mass Spectrometer. Anal. Chem. 1996, 68, 4033-4043.

13. Asam, M. R.; Glish, G. L. Tandem Mass Spectrometry of Alkali Cationized Polysaccharides in a Quadrupole Ion Trap. J. Am. Soc. Mass Spectrom. 1997, 8, 987-995.

14. Vachet, R. W.; Ray, K. L.; Glish, G. L. Origin of Product Ions in the MS/MS Spectra of Peptides in a Quadrupole Ion Trap. J. Am. Soc. Mass Spectrom. 1998, 9, 341-344.

15. Lin, T.; Glish, G. L. C-Terminal Peptide Sequencing via Multistage Mass Spectrometry. Anal. Chem. 1998, 70, 5162-5165.
16. Chu, I. K.; Shoeib, T.; Guo, X.; Rodriquez, C. F.; Hopkinson, A. C.; Siu, K. W. M.; Lau, T. C. Characterization of the Product Ions from the Collision-Induced Dissociation of Argentinated Peptides. J. Am. Soc. Mass Spectrom. 2001, 12, 163-175.

17. Grese, R. P.; Gross, M. L. Gas-Phase Interactions of Lithium Ions and Dipeptides. J. Am. Chem. Soc. 1990, 112, 5098-5104.

18. Grese, R. P. Cerny, R. L.; Gross, M. L. Metal Ion-Peptide Interactions in the Gas Phase: A Tandem Mass Spectrometry Study of Alkali Metal Cationized Peptides. J. Am. Chem. Soc. 1989, 111, 2835-2842.

19. Teesch, L. M.; Adams, J. J. Intrinsic Interactions between Alkaline Earth Metal Ions and Peptides: A Gas-Phase Study. J. Am. Chem. Soc. 1990, 112, $4110-4120$.

20. Teesch, L. M.; Adams, J. J. Fragmentations of Gas-Phase Complexes between Alkali Metal Ions and Peptides: Metal Ion Binding to Carbonyl Oxygens and Other Neutral Functional Groups. J. Am. Chem. Soc. 1991, $113,812-820$.

21. Nair, H.; Wysocki, V. H. Are Peptides without Basic Residues Protonated Primarily at the Amino Terminus? Int. J. Mass Spectrom. Ion. Processes 1998, 174, 95-100.

22. Yalcin, T.; Csizmadia, I. G.; Peterson, M. R.; Harrison, A. G. The Structure and Fragmentation of $b_{n}(n \geq 3)$ Ions in Peptide Spectra. J. Am. Soc. Mass Spectrom. 1996, 7, 233-242.

23. Wysocki, V. H.; Tsaprailis, G.; Smith, L. L.; Breci, L. A. Mobile and Localized Protons: A Framework for Understanding Peptide Dissociation. J. Mass Spectrom. 2000, 35, 1399-1406.

24. Burlet, O.; Yang, C. Y.; Gaskell, S. J. Influence of Cysteine to Cysteic Acid Oxidation on the Collision-activated Decomposition of Protonated Peptides: Evidence for Intraionic Interactions. J. Am. Soc. Mass Spectrom. 1992, 3, 337-344.

25. Fernandez Ocana, M.; Neubert, H.; Przyborowska, A.; Parker, R.; Bramley, P.; Halket, J.; Patel, R. BSE Control: Detection of GelatineDerived Peptidesin Animal Feed by Mass Spectrometry. Analyst 2004 $129,111-115$

26. Fernandez Ocana, M.; Jarvis, J.; Parker, R.; Bramley, P.; Halket, J.; Patel, R.; Neubert, H. C-Terminal Sequencing by Mass Spectrometry: Application to Gelatine-Derived Proline-Rich Peptides. Proteomics 2005, 5, 1209-1216. 